\title{
Drug Reaction with Eosinophilia and Systemic Symptoms Syndrome Associated with Ampicillin-Sulbactam and Clindamycin: A Case Report
}

\author{
Ampisilin-Sulbaktam ve Klindamisin-iliş̦kili Eozinofili ve Sistemik Semptomlarla Giden \\ İlaç Reaksiyonu Sendromu: Olgu sunumu \\ (D) Öner Özdemir1, (D) Gökçe Genç² \\ 1Sakarya University Training and Research Hospital, Clinic of Pediatrics, Division of Allergy and Immunology, Adapazarı, Turkey \\ 2Sakarya University Training and Research Hospital, Clinic of Pediatrics, Adapazarı, Turkey
}

\begin{abstract}
Drug reaction with eosinophilia and systemic symptoms (DRESS) syndrome is a life-threatening delayed type allergic reaction characterized by fever, skin rash, lymphadenopathy, eosinophilia and internal organ involvement. A 4-year-old male patient was admitted to the hospital with fever and rash. His medical history revealed use of an antibiotic combination (ampicillin + sulbactam and clindamycin) 2 weeks ago. Physical examination revealed hepatomegaly, splenomegaly, lymphadenopathy, fever and macular rash. The patient was diagnosed with DRESS syndrome with laboratory and clinical findings. The responsible medication was discontinued and corticosteroid was added to the treatment. DRESS syndrome should be kept in mind in patients with history of drug use, fever, skin rash and solid organ involvement.
\end{abstract}

Keywords: DRESS, eosinophilia, allergy, drug, hypersensitivity

\section{$\ddot{0} Z$}

Eozinofili ve sistemik semptomlarla giden ilaç reaksiyonu (DRESS) sendromu ateş, deri döküntüsü, lenfadenopati, eozinofili, iç organ tutulumu ile karakterize, yaşamı tehdit eden bir gecikmiş tip allerjik reaksiyonudur. Dört yaşında bir erkek hasta ateş ve döküntü ile hastaneye yatırıldı. Öyküsünde 2 hafta önce antibiyotik kombinasyonu (ampisilin + sulbaktam ve klindamisin) kullanımı mevcuttu. Fizik incelemede hepatomegali, splenomegali, lenfadenopati, ateş ve maküler döküntü saptandı. Laboratuvar ve klinik bulguları ile hastaya DRESS sendromu tanısı konuldu. Sorumlu ilaç kesildi ve tedaviye kortikosteroit eklendi. Illaç kullanım öyküsü, ateș, deri döküntüsü ve solid organ tutulumu olan hastalarda DRESS sendromu ayırıcı tanıda akılda tutulmalıdır.

Anahtar Kelimeler: DRESS, eozinofili, alerji, ilaç, hipersensitivite

\section{Introduction}

Drug reaction with eosinophilia and systemic symptoms (DRESS) syndrome is a rare, drug-induced, lethal, delayed drug hypersensitivity reaction in childhood (1-3). Clinical findings include drug-induced rash, eosinophilia in peripheral blood count, and systemic symptoms such as fever, lymph node involvement and other solid organ involvement (liver, kidney, lung, etc.) $(1,2)$. Although the most common cause is antiepileptic drugs, it is associated with many drugs such as antibiotics $(3,4)$.

Although the exact incidence of DRESS syndrome is unknown, it is thought to be 1.2-6 cases/million/year $(5,6)$. DRESS syndrome, especially for anti-convulsant drugs, is thought to be an immunological response to reactive metabolites that develop after a pharmacological defect in drug detoxification (6). This immunological response can also be triggered by viral infections such as Herpes infections (6-8). Here, we aimed to present our rare case in which we discuss the contribution of synchronous human parvovirus-B19 (HPV-B19) infection in the development of DRESS syndrome associated with the use of antibiotic combination (ampicillin + sulbactam and clindamycin).

\section{Case Report}

A 4-year-old male patient was admitted to our clinic because of prolonged and persistent fever. The patient had a fever that started 10 days prior to his admission. In his medical history, it was learned that he had been treated with empirical antibiotic (ampicillin + sulbactam and clindamycin) for 6 days and his fever persisted. The patient had no problems in his prenatal, natal and family history. On 
his physical examination, his general condition was good and he was conscious. His vital signs were as follows: body temperature: $38.2^{\circ} \mathrm{C}$, pulse: $125 / \mathrm{min}$ and blood pressure: $90 / 60 \mathrm{~mm} / \mathrm{Hg}$. The patient had new-onset maculo-papular rash on his face and whole body (Figures 1,2). Facial rashes and peelings on the palm and fingers suggested HPV-B19 infection, however, dermatitis in the DRESS syndrome was also suspected (Figure 3). Physical examination also revealed diffuse maculopapular rash, $2 \mathrm{~cm}$ hepatomegaly, $3 \mathrm{~cm}$ splenomegaly, bilateral cervical

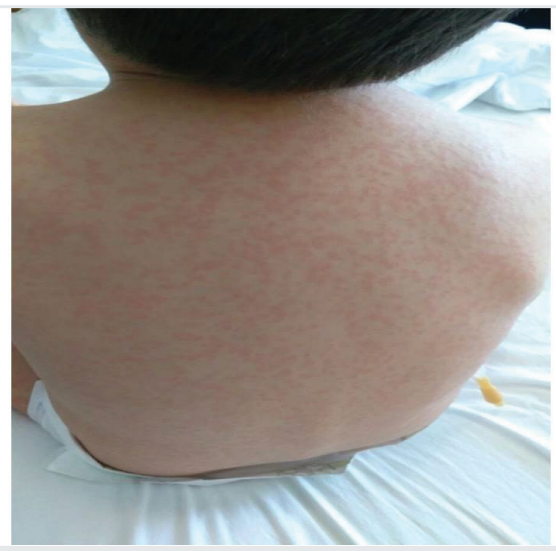

Figure 1. Maculo-papular rashes are seen in the back of our patient

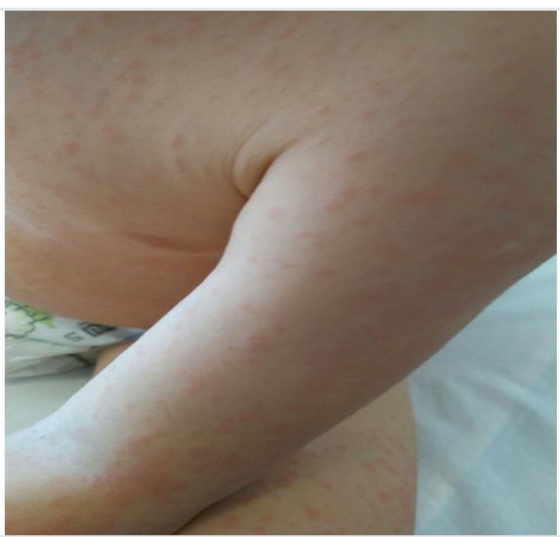

Figure 2. Maculo-papular rashes in the trunk, arm and thigh



Figure 3. Maculo-papular rashes in the hands and feet, and peeling in the hand and inguinal lymphadenopathy without clear fever focus. Other system examination findings were normal. Laboratory findings were as follows: hemoglobin: $10.2 \mathrm{~g} / \mathrm{dL}$, white blood cell count: $14.400 / \mathrm{mm}^{3}$, platelet count: $330.000 / \mathrm{mm}^{3}$. Peripheral blood smear revealed eosinophilia (4\%, absolute eosinophil count: $545 / \mathrm{mm}^{3}$ ) and reactive (atypical) lymphocytes. Complete biochemistry and urinalysis were normal, and blood and urine cultures were negative. C-Reaktif Protein was $36 \mathrm{mg} / \mathrm{L}$ and sedimentation was $44 \mathrm{~mm} / \mathrm{h}$. Although HPV-B19 Immunoglobulin M (IgM) was positive in serology, HPV-B19 IgG could not be studied. The polymerase chain reaction (PCR) for parvovirus was negative. The patient's history and clinical findings were consistent with DRESS syndrome. According to the RegiSCAR scoring, our patient had $>5$ points (seven) (Table 1). The drugs (ampicillin + sulbactam and clindamycin) that were considered to be responsible were discontinued immediately. Corticosteroid $(1 \mathrm{mg} / \mathrm{kg} /$ day, methylprednisolone) and feniramine maleate ( $2 \mathrm{mg} / \mathrm{kg} /$ day) were started. After the first doses of treatment, the patient's fever receded. Hepatomegaly, splenomegaly and lymphadenopathies regressed with one-week steroid therapy. Corticosteroid was reduced and discontinued, and feniramine was discontinued without reduction within 1 week. The patient, who showed clinical improvement, was discharged for outpatient follow-up. In order to get rid of the effects of drugs and to get optimal results, a patch test was planned within 2 to 6 months after the discharge, however, it could not be done because the family moved to another city. Both oral and written consent were obtained from the patient's parents for this case report.

\section{Discussion}

The diagnostic criteria for DRESS syndrome have been described in the literature (9). Presence of more than 3 following criteria in a patient is considered diagnostic for DRESS syndrome: sudden onset of skin rash, $>38{ }^{\circ} \mathrm{C}$ fever, lymphadenomegaly in at least two regions, at least one solid organ involvement, and laboratory findings (hematological abnormalities: eosinophilia, lymphocytosis, thrombocytopenia and atypical lymphocytes) (4-10).

High fever occurs in almost all cases and begins at the same time as the rash. The rash is usually in the form of maculo-papular exanthema. Bullae, pustule, purpura, plaque, erythrodermia and even exfoliative dermatitis may be observed $(4,5,11,12)$. In DRESS syndrome, the most commonly affected solid organ is liver, kidney, lung and heart, respectively $(5,13)$. Eosinophilic infiltration is seen in the involved organs (5). Transaminases and serum creatinine increases due to involvement $(4,5,14)$. In our case, there were maculo-papular rash after drug use and fever for at least 10 days. In our patient, eosinophilia $\left(>500 / \mathrm{mm}^{3}\right)$ was also present in the peripheral smear. The presence of hepatomegaly and splenomegaly in our patient showed solid organ involvement. Renal functions, chest X-ray, respiratory and cardiovascular examination were normal. The patient with prolonged fever and rash after drug use was evaluated as DRESS syndrome with clinical findings and Regiscar scoring. Clinical findings in DRESS syndrome occur 2-8 weeks after taking the drug (4). In our patient, this period was approximately 2 weeks.

Our case met the criteria with fever, rash, liver involvement, lymphadenopathy and eosinophilia. The RegiSCAR scoring system developed by Kardaun et al. (15) for the diagnosis of DRESS syndrome 
has a total score between -4 and 9 , and is divided into no cases $(<2$ points), possible (2-3 points), probable (4-5 points) and definite DRESS syndrome (>5 points) (Table 1). The Regiscar scoring was as follows in our patient: fever: 0 point, lymphadenopathy: 1 point, eosinophilia: 0 point, atypical lymphocytes in peripheral smear: 1 point, skin rash: 2 points, liver and spleen involvement: 2 points, rash resolution $>15$ days: 0 point and excluding other causes: 1 point, a total of 7 points. The diagnosis of DRESS syndrome was confirmed by $>5$ points in Regiscar evaluation.

The most commonly responsible drugs from DRESS syndrome are aromatic (phenytoin, phenobarbital, carbamazepine, etc.) anti-convulsants. Rarely, other anti-epileptics, antibiotics such as sulfonamide, dapsone, allopurinol, anti-inflammatory drugs have also been reported as the cause (4,6,13-17). In a study performed by Kundak et al. (14), DRESS syndrome following amoxicillin use was defined. Again, in the RegiScar study by Kardaun et al. (15), which included 201 possible DRESS cases, one of the cases who developed DRESS with 13 antibiotics was the patient who used ampicillin/sulbactam. In addition, our patient also used clindamycin and this antibiotic was reported in the near future to cause DRESS syndrome in the literature (17). The fact that the same group of antibiotics was used together in our case suggests that antibiotics may be responsible for the development of the clinical picture. Although it is reported in the literature that DRESS syndrome is usually developed with anti-convulsant drugs, DRESS syndrome following antibiotic use reported in previous articles from our country and other countries, as in our case, is important in terms of demonstrating this possibility $(14,17)$.

The role of antibiotics in the development of DRESS syndrome can be demonstrated by antibiotic-mediated lymphocyte transformation test and patch test since drug provocation in such clinical situations is risky and not recommended $(18,19)$. These tests should be done if necessary, in order to determine the agent and to avoid them in the future, although the results are not very reliable. Positive results are more valuable than negative results. The negative and positive predictive values of these tests are not known. Although patch test with anti-epileptics such as carbamazepine gives good results, it has been reported that the positive predictive value of other drugs such as allopurinol varies between 0-10\% (19-22). Although there are no serious side effects associated with patch test, there are rare reports of serious side effects with recurrence in the literature (23). As the patient could not come to the follow-up due to moving from the city, patch test for antibiotics could not be performed.

\begin{tabular}{|c|c|c|c|c|c|c|}
\hline Score (points) & -1 & 0 & 1 & 2 & Min. & Max. \\
\hline Fever $\geq 38.5^{\circ} \mathrm{C}$ & $\mathrm{N} / \mathrm{U}$ & $\mathrm{Y}$ & - & - & -1 & 0 \\
\hline Enlarged lymph nodes & - & $N / U$ & Y & - & 0 & 1 \\
\hline Eosinophilia & - & $N / U$ & & - & 0 & 2 \\
\hline Eosinophil & - & $700-1.499 / \mathrm{mm}^{3}$ & $\geq 1.500 / \mathrm{mm}^{3}$ & - & - & - \\
\hline Eosinophil (if leukocyte $<4.000 / \mathrm{mm} 3$ & - & $10-19.9 \%$ & $20 \%$ & - & - & - \\
\hline Atypical lymphocytosis & - & $N / U$ & Y & - & 0 & 1 \\
\hline Skin involvement & - & - & - & - & -2 & 2 \\
\hline Extent (body surface area \%) & - & $N / U$ & $>\% 50$ & - & - & - \\
\hline Rash suggesting DRESS & $\mathrm{N}$ & U & Y & - & - & - \\
\hline Skin biopsy suggesting DRESS & $\mathrm{N}$ & $\mathrm{Y} / \mathrm{U}$ & - & - & - & - \\
\hline Organ involvement* & - & - & - & - & 0 & 2 \\
\hline Liver & - & $N / U$ & Y & - & - & - \\
\hline Kidney & - & $N / U$ & Y & - & - & - \\
\hline Lungs & - & $N / U$ & Y & - & - & - \\
\hline Heart/Muscle & - & $N / U$ & Y & - & - & - \\
\hline Pancreas & - & $N / U$ & Y & - & - & - \\
\hline Other organs & - & $N / U$ & Y & - & - & - \\
\hline Rash resolution $\geq 15$ days & $N / U$ & Y & - & - & -1 & 0 \\
\hline Excluding other causes & - & - & - & - & 0 & 1 \\
\hline Anti-nuclear antibody (ANA) & - & - & - & - & - & - \\
\hline Blood culture & - & - & - & - & - & - \\
\hline Serology for HAV/HBV/HCV & - & - & - & - & - & - \\
\hline $\begin{array}{l}\text { Chlamydia/Mycoplasma } \\
\text { (If three tests of the following tests were performed and all were } \\
\text { negative) }\end{array}$ & - & - & $Y$ & - & - & - \\
\hline Total Score & & & & - & -4 & 9 \\
\hline \multicolumn{7}{|c|}{$\begin{array}{l}\text { Total score: no cases (<2 points), possible ( } 2-3 \text { points), probable ( } 4-5 \text { points) and definite DRESS syndrome ( }>5 \text { points). *After exclusion of other causes 1: one organ involvement, 2: show } \\
\text { two or more organ overalls. }\end{array}$} \\
\hline
\end{tabular}


Although DRESS syndrome is a type of delayed type (type IV) drug hypersensitivity reaction, its ethiopathogenesis is not clear today. Among the factors implicated in ethiopathogenesis are enzyme defects of drug metabolism, lymphocyte activation, eosinophilia and viral agents (especially human herpesvirus-6 and 7) (5). In addition, it was observed that cytomegalovirus and Epstein-Barr virus infections from the herpesvirus family were also reported to be related or triggering causes (4-7). Although there has been no previously reported case of HPV-B19 in the literature $(24,25)$ except for 1 -2 cases, the presence of symptoms (fever, rash, and peeling on hands and feet), HPV-B19 IgM positivity (despite PCR negativity and IgG not examined) in our case suggests that parvovirus can also be a related factor. As a result of the microbiology consultation, it was learned that PCR performed in the early period of viremia and/or PCR kit being not very sensitive might be the reason for PCR negativity and that PCR could not always show that the patient was not infected.

HPV-B19 cases reported in the literature, as reported by Regnier et al. (24), suggested that infection might cause clinical situations that can mimic DRESS syndrome or that this infection occur during the clinical course of DRESS syndrome (reactivation) and prolongs the course of disease and complicates the clinical status. Regnier et al. (24) and Coughlin et al. (25) reported that HPV-B19 infection was detected in three cases after DRESS disease or after recurrent transaminitis (hepatic transaminase elevation). The steroid therapy was continued for 20 weeks in one case and for 7 weeks in the other. In our case, transaminase values were within normal limits from the beginning to the end of the disease course. This, in addition to the IgM positivity, makes us think the effect of HPV-B19 on the clinical picture of our patient as the transaminases were within normal limits and PCR was negative. Perhaps, anti-HPV-B19 IgM positivity may also be coincidental. In conclusion, it is difficult to explain whether the clinical picture of DRESS in our case is due to virusdrug interaction or the effect of drugs on its own.

The basic for the management of DRESS syndrome is the immediate discontinuation of the suspected drug or drugs and the supportive treatment (3). Topical corticosteroids, moisturizers and H1-antihistamines in case of mild symptoms, prednisolone $1 \mathrm{mg} / \mathrm{kg} / \mathrm{day}$ in the presence of severe symptoms (5-fold increase in transaminases, pneumonia, hemophagocytosis, cardiac involvement, solid organ involvement, etc.), $0.5-2 \mathrm{~g} / \mathrm{kg} /$ dose Intravenous Ig (IVIG) in case of life-threatening symptoms (hemophagocytosis, encephalitis, severe hepatitis, renal insufficiency, respiratory failure, etc.) and combination of steroid, antiviral agents and/or IVIG is recommended in the presence of severe symptoms with major viral reactivation $(5,18)$. In our case, corticosteroid was given from $1 \mathrm{mg} / \mathrm{kg} / \mathrm{day}$ due to solid organ involvement. The patient's fever, rash and organomegaly were dramatically regressed. Corticosteroids were reduced and discontinued within 1 week. The patient who showed clinical improvement was discharged with outpatient follow-up.

\section{Conclusion}

DRESS syndrome, which is a life-threatening reaction when its diagnosis is delayed, should be considered in the differential diagnosis in patients with prolonged fever, rash, lymphadenopathy, solid organ involvement and prior drug use.
Informed Consent: Both oral and written consent were obtained from the patient's parents for this case report.

Peer-review: Externally peer-reviewed.

Author Contributions: Concept - Ö.Ö.; Design - Ö.Ö., G.G.; Supervision - Ö.Ö.; Resources - Ö.Ö., G.G.; Materials - G.G.; Data Collection and/or Processing - G.G.; Analysis and/ or Interpretation - Ö.Ö.; Literature Search - G.G.; Writing Manuscript - Ö.Ö., G.G.; Critical Review - Ö.Ö.

Conflict of Interest: There is no conflict of interest with any institution or company.

Financial Support: The authors declared that they did not receive financial support for this study.

\section{References}

1. Cacoub P, Musette P, Descamps V, Meyer O, Speirs C, Finzi L. The DRESS syndrome: A literature review. Am J Med 2011; 124: 588-97.

2. Husain Z, Reddy BY, Schwartz RA. DRESS syndrome, Part I: Clinical perspectives J Am Acad Dermatol 2013; 68: 693-705.

3. Kardaun SH, Sidoroff A, Valeyrie-Allanore L, Halevy S, Davidovici BB, Mockenhaupt $\mathrm{M}$, et al. Variability in the clinical pattern of cutaneous sideeffects of drugs with systemic symptoms: Does a DRESS syndrome really exist? $\mathrm{Br}$ J Dermatol 2007; 156: 609-11.

4. Ucal-Bakkal S, Kocak-Tufan Z, Bulut C. A case of DRESS syndrome mimicking sepsis. Klimik Dergisi 2011; 24: 132-4.

5. Canitez Y, Poyraz Efe H, Sapan N. Carbamazepine-related DRESS syndrome; a rarely seen drug hypersensitivity reaction: Türkiye Çocuk Hast Derg 2015; 1: 147-51.

6. Oskay T, Karademir A, Ertürk OI. Association of anticonvulsant hypersensitivity syndrome with Herpesvirus 6, 7. Epilepsy Res. 2006; 70: 27-40.

7. Nanishi E, Hoshina T, Ohga S, Nishio H, Hara T. Drug reaction with eosinophilia and systemic symptoms during primary Epstein-Barr virus infection. J Microbiol Immunol Infect 2015; 48: 109-12.

8. Criado PR, Avancini J, Santi CG, Medrado AT, Rodrigues CE, de Carvalho JF. Drug reaction with eosinophilia and systemic symptoms (DRESS): A complex interaction of drugs, viruses and the immune system. Isr Med Assoc J 2012; 14: 577-82.

9. Yılmaz EA, Özmen S, Tuygun N. Lamotrijin ilișkili DRESS sendromu: bir vaka sunumu. Çocuk Dergisi 2009; 9: 142-6.

10. Chiou CC, Yang LC, Hung SI, Chang YC, Kuo TT, Ho HC, et al. Clinicopathological features and prognosis of drug rash with eosinophilia and systemic symptoms: a study of 30 cases in Taiwan. J Eur Acad Dermatol Venereol 2008; 22: 1044-9.

11. Peyriere H, Dereure $\mathrm{O}$, Breton H, Demoly P, Cociglio M, Blayac JP, et al. Variability in the clinical pattern of cutaneous side-effects of drugs with systemic symptoms: does a DRESS syndrome really exist? Br J Dermatol 2006; 155: 422-8.

12. Saha M, Gorai S, Madhab V. Oxcarbazepine-induced drug rash with eosinophilia and systemic symptoms syndrome presenting as exfoliative dermatitis. J Pharmacol Pharmacother 2016; 7: 142-5.

13. Knowles SR, Dewhurst N, Shear NH. Anticonvulsant hypersensitivity syndrome: An update. Expert Opin Drug Saf 2012; 11: 767-78.

14. Kundak S, Öner EI, Bağ İnce Ö. Sülfasalazin ile birlikte Amoksisilin kullanımına bağlı gelișen DRESS sendromu. Turkiye Klinikleri J Dermatol 2016; 26: 184-90.

15. Kardaun SH, Sekula P, Valeyrie-Allanore L, Liss Y, Chu CY, Creamer D, et al. Drug reaction with eosinophilia and systemic symptoms (DRESS): an original multisystem adverse drug reaction. Results from the prospective RegiSCAR study. Br J Dermatol 2013; 169(5):1071-80. 
16. Girelli F, Bernardi S, Gardelli L, Bassi B, Parente G, Dubini A, et al. A new case of DRESS syndrome induced by Sulfasalazine and triggered by Amoxicillin. Case Rep Rheumatol 2013; 2013: 409152.

17. Karakayalı B, Yazar AS, Çakir D, Cetemen A, Kariminikoo M, Deliloglu B, et al. Drug Reaction with Eosinophilia and Systemic Symptoms (DRESS) syndrome associated with cefotaxime and clindamycin use in a 6 year-old boy: a case report. Pan Afr Med J 2017; 28: 218.

18. Descamps V, Ben-Saïd B, Sassolas B, Truchetet F, Avenel-Audran M, Girardin P, et al. Management of drug reaction with eosinophilia and systemic symptoms (DRESS). Ann Dermatol Venereol 2010; 137: 703-8.

19. Husain Z, Reddy BY, Schwartz RA. DRESS syndrome: Part II. Management and therapeutics. J Am Acad Dermatol 2013; 68: 709.

20. Santiago F, Goncalo M, Vieira R, Coelho S, Figueiredo A. Epicutaneous patch testing in drug hypersensitivity syndrome (DRESS). Contact Derm 2010; 62: 47-53.
21. Elzagallaai AA, Knowles SR, Rieder MJ, Bend JR, Shear NH, Koren G. Patch testing for the diagnosis of anticonvulsant hypersensitivity syndrome: a systematic review. Drug Safety 2009; 32: 391-408.

22. Pinho A, Coutinho I, Gameiro A, Gouveia M, Gonçalo M. Patch testing - a valuable tool for investigating non-immediate cutaneous adverse drug reactions to antibiotics. J Eur Acad Dermatol Venereol 2017; 31: 280-7.

23. Shebe K, Ngwanya MR, Gantsho N, Lehloenya RJ. Severe recurrence of drug rash with eosinophilia and systemic symptoms syndrome secondary to rifampicin patch testing in a human immunodeficiency virus-infected man. Contact Dermatitis 2014; 70: 125-7.

24. Regnier S, Descamps V, Boui M, Lebrun-Vignes B, Descamps D, Grossin M, et al. (Parvovirus B19 infection mimicking drug-induced hypersensitivity syndrome). Ann Dermatol Venereol 2000; 127: 505-6.

25. Coughlin CC, Jen MV, Boos MD. Drug hypersensitivity syndrome with prolonged course complicated by Parvovirus infection. Pediatr Dermatol 2016; 33: 364-5 